\title{
Study on the Trade Potential of BRIC Countries_Empirical Analysis Based on Gravity Model
}

\author{
Pei-Zhi WANG ${ }^{1, a}$, Zhe-Ning $\mathrm{YU}^{2, \mathrm{~b},}$ and $\mathrm{Yu}$-Han ZHENG ${ }^{3, c}$ \\ ${ }^{1}$ Shandong University of Finance and Economics, Jinan, China \\ ${ }^{2}$ Shandong University of Finance and Economics, Jinan, China \\ ${ }^{3}$ Shandong University of Finance and Economics, Jinan, China \\ a wpzmail@126.com, ${ }^{\mathrm{b}}$ ljxyzn@163.com, candy19940119@163.com
}

Keywords: BRIC countries, Comparative advantage, Gravity model, Trade potential.

\begin{abstract}
In recent years, BRIC countries, as a representative of emerging economies, have increasingly become an important driving force driving the global economic recovery. This paper studies the trade import and export of the BRIC countries through statistical analysis and econometric methods. First of all, based on the data of import and export of BRIC countries from 2010 to 2016, this article gives an overview of the current situation of BRIC countries' trade development, mainly from the ratio of the internal trade volume to the total export volume of the BRIC countries and the mutual import and export between the BRIC countries. Secondly, systematically calculating the international competitiveness of BRICS by calculating the dominant comparative advantage index. Thirdly, based on the data, using the gravity model to analyze the impact of inter-state. And based on this, through calculating the regression equation, this paper systematically analyzes the trade development potentials between BRIC countries. Finally, it briefly summarizes the main conclusions of this paper, and give the relevant policy recommendations.
\end{abstract}

\section{Introduction}

In recent years, against the background of the sluggish global economic growth, BRICS, as an important engine for boosting global economic growth, has maintained a momentum of rapid development in economic, cultural and cultural exchanges. In 2016, BRICS GDP has exceeded 16.8 trillion dollars, accounting for $22.26 \%$ of the world total. This is an important achievement of the BRICS member countries in jointly promoting development. BRIC countries have $40 \%$ of the world's population, across three continents, BRICS GDP has accounted for about $20 \%$ of the world.

As the largest developing country in the world, China became the world's number one trade country of goods by 2013 with 4.16 trillion dollars of import and export volume after becoming the world's largest exporter.

Since the crisis in Ukraine in 2014, Russia has been in a state of economic downturn for many years, its foreign trade volume has dropped but its trade surplus has been increasing. It ranked the 12th in the world with a GDP of 1,267.7 billion dollars in 2016. In particular, as a neighboring country, China and Russia have always maintained close and friendly trade partnerships and maintained their position as China's largest oil supplier for the eighth consecutive month.

Brazil has a solid industrial base with GDP ranking first in Latin America and the seventh largest economy in the world, with the aircraft manufacturing industry among the highest in the world. In 2016, Brazil's GDP was 1,769.6 billion dollars, ranking the ninth in the world.

As the second largest populous country in the world, India has become an important exporter of global financial, software and other service industries. As one of the fastest-growing economies in the world, India has witnessed a rapid pace of development. India's GDP was 447.5 billion dollars in 2011, and the second highest in the world in 2016 with 2.2259 billion dollars.

As the second largest economy in Africa, South Africa enjoys an excellent geographical location. It is located across the Indian Ocean from Australia and across the Atlantic Ocean from Brazil and 
Argentina. It is known as the "Western Lifeline of the Sea." And it is a unique geographical location that makes South Africa a world One of the busiest sea lanes.

\section{The Current Situation of BRICS Trade Development}

From the perspective of trade scale, the total export trade volume of BRIC countries were 2,479.78 billion dollars in 2010, accounting for $14.25 \%$ of the total world's export trade volume, up to $17.7 \%$ in 2011 and 19.25\% in 2016. Although the data in Table 1 shows the "mountain-like" fluctuations in the total internal export trade and export trade in the BRICS after the first increase and then decrease, the total export trade of the BRICS countries are indeed increasing year by year.

Table 1 from 2010 to 2016, BRICS internal trade volume, the world's total export trade and the ratio of the two

\begin{tabular}{|l|l|l|l|l|l|l|l|}
\hline & 2010 & 2011 & 2012 & 2013 & 2014 & 2015 & 2016 \\
\hline Internal export trade & 2107.54 & 2749.33 & 2814.08 & 2964.00 & 2952.89 & 2421.79 & 2347.69 \\
\hline Total export trade & 24797.80 & 30808.49 & 32045.64 & 34100.29 & 34733.81 & 31425.15 & 29028.01 \\
\hline $\begin{array}{l}\text { Internal trade accounted } \\
\text { for the total export trade } \\
\text { ratio }\end{array}$ & 8.50 & 8.92 & 8.78 & 8.69 & 8.50 & 7.71 & 8.09 \\
\hline
\end{tabular}

Data source: Calculated based on the corresponding data from the UN Statistical Office.

Table 2 Distribution of import and export trade among BRICS countries in 2016

\begin{tabular}{|c|c|c|c|c|c|c|c|}
\hline & China & Russia & India & Brazil & South Africa & $\begin{array}{c}\text { Total } \\
\text { exports }\end{array}$ & $\begin{array}{c}\text { The } \\
\text { proportion }\end{array}$ \\
\hline China & & 373.39 & 583.98 & 219.76 & 128.50 & 1305.63 & 55.61 \\
\hline Russia & 280.21 & & 53.13 & 17.86 & 1.96 & 353.16 & 15.04 \\
\hline India & 89.16 & 18.14 & & 23.00 & 32.43 & 162.73 & 6.93 \\
\hline Brazil & 351.34 & 23.00 & 31.61 & & 13.97 & 419.92 & 17.89 \\
\hline South Africa & 68.12 & 2.83 & 31.51 & 3.78 & & 106.24 & 4.53 \\
\hline Total imports & 788.83 & 417.36 & 700.23 & 264.40 & 176.86 & 2347.68 & \multirow[b]{2}{*}{100} \\
\hline $\begin{array}{c}\text { The } \\
\text { proportion }\end{array}$ & 33.60 & 17.78 & 29.83 & 11.26 & 7.53 & & \\
\hline
\end{tabular}

Data source: Calculated based on the corresponding data from the UN Statistical Office.

Note: The horizontal heading indicates the exporting country and the vertical heading indicates the importing country.

From the perspective of trade surplus, it is shown in the Table 2, China still holds the dominant position in the BRIC countries, with China's exports accounting for $55.61 \%$ of the total BRICS exports and China's imports accounting for $33.60 \%$ of the total imports, with a total of 51.68 billion dollars. Only Brazil, the other BRIC country, made a trade surplus of 15.552 billion dollars. Russia, India and South Africa both have trade deficits with a deficit of 64.253 billion dollars and 70.62 billion dollars respectively.

\section{BRIC Countries Trade Competitiveness}

The main reason for the international division of labor and trade is the comparative advantage difference between countries. The factor of production endowment and the level of production technology in a country determine the comparative advantage of each country. [The theory of resource endowment proposed by Heckscher and Ohlin, For the neoclassical trade theory, the differences in prices caused by the relative endowment differences lead to international trade and international division of labor. ]. In this paper, we use the Revealed Comparative Advantage Index 
(RCA) proposed by the American economist Balassa Bela (1965) to calculate the respective comparative advantages of the BRIC countries.

The dominant comparative advantage index refers to the ratio of the share of a country's total exports to that of the world's exports in the world's total exports. The index is formulated as:

$$
R C A_{\mathrm{ak}}^{X}=\left(X_{\mathrm{ak}} / X_{\mathrm{a}}\right) /\left(W_{\mathrm{k}} / W\right)
$$

Which $R C A_{\mathrm{ak}}^{x}$ represents the dominant comparative advantage index of a country in k-type goods, which $X_{\text {ak }}$ shows the export amount of k-type goods in a-country, ${ }^{\text {a }}$ shows the total exports of a-country, $W_{\mathrm{k}}$ shows the exports of k-type goods in the world, and $W$ shows the world total exports. The index of dominant comparative advantage is usually used to reflect the competitiveness of a country's export products. According to the Japan Rehabilitation Association's standard, when it is less than 0.8, its export has a weak international competitiveness. When greater than 0.8 and less than 1.25, the product exports With a moderate international competitiveness; when greater than 1.25 and less than 2.5, the export of the product has strong international competitiveness; when greater than 2.5, the country's exports have a very strong international competitiveness. In this paper, the classification standard of SITC Rev.4 is used to divide the exported products of BRICS countries into ten categories for statistical analysis from 2010 to 2016.

China has strong international competitiveness in labor-intensive products, especially SITC-8 miscellaneous products; Russia has a strong comparative advantage in SITC-3 fossil fuels, lubricants and related raw materials products in primary products; India There is a strong comparative advantage in labor-intensive products, especially SITC-6, which is mainly classified by materials. There is a clear comparative advantage in the primary products of SITC-0 grain and the mainly live animal products for consumption; Brazil has strong international competitiveness in primary products SITC-0 and SITC-2; South Africa has a clear comparative advantage in primary products, especially in the non-edible raw materials other than raw materials SITC-2 has Strong international competitiveness. Therefore, China's international competitiveness in primary products is relatively weak. The comparative advantages of Russia and Brazil in labor-intensive and capital-intensive and technology-intensive products are relatively weak. The international competition between India and South Africa in capital and technology-intensive products Weak force.

\section{An Empirical Analysis of Bilateral Trade between BRIC Countries}

\section{Model Construction and Variable Selection}

Based on the study of gravitation model of Anderson and van Wincoop (2003), this paper introduces the GDP of the two countries, the distance between the capitals of the two countries and whether the two countries signed free trade agreements and other related variables, and constructs the trade gravity model as follows:

$$
\text { LnYijt }=\beta 0+\beta 1 \mathrm{LnGDPi}+\beta 2 \mathrm{LnGDPj}+\beta 3 \mathrm{LnDISTij}+\beta 4 \mathrm{FTAijt}+\mu \mathrm{ijt}
$$

Among them, $\beta_{0}, \beta_{1}, \beta_{2}, \beta_{3}, \beta_{4}$ represent regression coefficients, $\mu_{\mathrm{ijt}}$ represent random errors or random disturbances.

\section{Empirical Results Analysis}

First of all, we use STATA13.0 software to regression analysis of bilateral trade gravitation, and get three empirical results in Table 3, which are mixed OLS model, stochastic effect model and fixed effect model respectively. Through the regression results, we can see that all the regression coefficient symbols of the explanatory variables are basically in line with expectations, and all passed the $1 \%$ significance level test. Through the comparison of the three models, the final effect model was selected. 
Table 3 Empirical results of the bilateral trade gravity model between China and its trading

\begin{tabular}{|c|c|c|c|}
\hline & (1) & (2) & (3) \\
\hline VARIABLES & $\ln Y_{i j t}$ & $\ln Y_{\mathrm{ijt}}$ & $\ln Y_{i j t}$ \\
\hline $\operatorname{lnGDP}_{\mathrm{i}}$ & $0.498 * * *$ & $0.498 * * *$ & $0.469 * * *$ \\
\hline & $(0.0411)$ & $(0.0767)$ & $(0.0689)$ \\
\hline $\operatorname{lnGDP}_{i}$ & $0.789 * * *$ & $0.789 * * *$ & $0.906 * * *$ \\
\hline & $(0.0706)$ & $(0.102)$ & $(0.165)$ \\
\hline$\overline{\operatorname{lnDIST}}_{\mathrm{ii}}$ & $-0.667 * * *$ & $-0.667 * * *$ & \\
\hline & $(0.230)$ & $(0.219)$ & \\
\hline FTA $_{\text {iit }}$ & $0.409 * * *$ & $0.409 * * *$ & $0.372 * * *$ \\
\hline & $(0.0896)$ & $(0.0749)$ & $(0.0620)$ \\
\hline Constant & -0.804 & -0.804 & $-7.375 * * *$ \\
\hline & $(2.030)$ & $(1.887)$ & $(1.713)$ \\
\hline Observations & 170 & 170 & 170 \\
\hline R-squared & & & 0.800 \\
\hline Number of id & 17 & 17 & 17 \\
\hline
\end{tabular}

Standard errors in parentheses $* * * \mathrm{p}<0.01, * * \mathrm{p}<0.05, * \mathrm{p}<0.1$

According to the above regression results, we can get the regression equation of random effects model:

$$
\operatorname{LnY}_{\mathrm{ijt}}=-0.804+0.498 \operatorname{LnGDP}_{\mathrm{i}}+0.789 \operatorname{LnGDP}_{\mathrm{j}}-0.667 \operatorname{LnDIST}_{\mathrm{ij}}+0.409 \mathrm{FTA}_{\mathrm{ijt}}+\mu_{\mathrm{ijt}}
$$

In terms of the national economic scale, the regression coefficient of the economies of scale of sample countries is the largest. In other words, the economies of sample countries have the greatest impact on the total volume of bilateral trade and imports, which is the main reason for promoting bilateral trade. Because big powers and big powers based on political and economic factors and other factors, the trade between each other more closely, a variety of products of large import and export volume, thus promoting the growing bilateral trade volume.

Judging from the distance between the national capitals, there is a significant inhibitory effect on the significant negative correlation with the bilateral trade volume. The longer the distance between the two countries, the greater the cultural and political differences, the higher the transportation cost and the higher the cost of trade. As a result, the trade relations between countries become even more distant, resulting in lower bilateral trade flows; on the contrary, the two countries The closer the distance between the two countries is, the closer the trade between countries will be, resulting in the higher bilateral trade flows between the two countries.

Judging from whether or not to sign a free trade agreement, there is a clear positive role in promoting the positive correlation between free trade agreements signed by countries and regions and bilateral trade flows. Countries or regions to sign free trade agreements, the reduction of tariffs on imports and exports, reducing trade barriers, to a large extent, to achieve trade liberalization.

\section{Analysis of the Development Potential of BRIC Countries Bilateral Trade}

The trade development potential index is the ratio of the actual trade volume to the theoretical estimated trade volume of the gravitation model obtained. The specific formula is:

$$
\mathrm{TP}_{\mathrm{t}}=\mathrm{TV}_{\mathrm{t}} / \mathrm{SV}_{\mathrm{t}}
$$

Among them, $\mathrm{TP}_{\mathrm{t}}$ represents the bilateral trade potential for development in $\mathrm{t}$ period, $\mathrm{TV}_{\mathrm{t}}$ represents the actual value of bilateral trade in period $t$, and $\mathrm{SV}_{\mathrm{t}}$ represents the theoretical estimate of bilateral trade in period t.

The trade potential between China and Russia, India and Brazil is modest, there is a certain space for trade promotion, and countries can stimulate the development of bilateral trade by cultivating new 
elements. However, the trade potential between China and South Africa is relatively small, However, it can not deny the future trade between the two countries. By formulating the relevant policy elements, the government can still further stimulate the development of bilateral trade.

Table 4 Bilateral trade potential for development between China and other BRIC countries from 2007 to 2016

\begin{tabular}{|l|l|l|l|l|l|l|l|l|l|l|}
\hline Year & 2007 & 2008 & 2009 & 2010 & 2011 & 2012 & 2013 & 2014 & 2015 & 2016 \\
\hline China-Russia & 1.01 & 0.99 & 0.96 & 0.97 & 0.98 & 0.98 & 0.97 & 0.98 & 0.97 & 0.98 \\
\hline China-India & 0.94 & 0.97 & 0.92 & 0.94 & 0.94 & 0.92 & 0.90 & 0.90 & 0.90 & 0.89 \\
\hline China-Brazil & 1.04 & 1.08 & 1.05 & 1.06 & 1.07 & 1.07 & 1.06 & 1.05 & 1.06 & 1.05 \\
\hline $\begin{array}{l}\text { China-South } \\
\text { Africa }\end{array}$ & 1.10 & 1.13 & 1.09 & 1.13 & 1.20 & 1.24 & 1.26 & 1.24 & 1.20 & 1.16 \\
\hline
\end{tabular}

Data Source: Calculated based on the regression equation.

\section{Related Policy Recommendations}

\section{Strengthen the Economic and Trade Cooperation between BRIC Countries and Promote the Free Flow of Elements}

On the one hand, China should step up its economic and trade cooperation with the other four countries. On the one hand, it should increase its investment in advantageous industries in its partner countries, especially its cooperation with the less developed primary products. With the help of the advantageous industries in partner countries, China can not only ensure the production of its products On the other hand, China should take the initiative to invest its own advantageous industries in partner countries, especially high-speed rail and other capital and technology-intensive industries in China, so that both the supply of raw materials and the supply of raw materials will be sufficient to promote the recovery and development of the dominant industries of partner countries. Give full play to the superiority of China's advantageous industries and help the partner countries to achieve the transformation of industrial upgrading.

\section{To Achieve Multilateral Trade Cooperation between BRIC Nations and Exert International Influence}

In the face of the new challenges in the new century in the world, the BRICS clearly have certain advantages. China has great advantages in the field of electronic commerce, especially in cross-border payments. As a coastal country of Brazil, India and South Africa, and in particular South Africa, which has the reputation of "the western maritime lifeline", China has a large As a speaker, Russia and South Africa, as the countries closest to the North Pole and Antarctica, have a great international influence on the polar issues and so on.

\section{Strengthen BRIC Trade Competitiveness, and Firmly Oppose Trade Protectionism}

The BRICS industries have different comparative advantages. It has become the most important task to actively invest in the advantageous industries of partner countries and to promote the transformation and upgrading their advantageous industries. Only by promoting trade complementarity can enhance the international competitiveness of our products more rapidly. Faced with the new challenges of the 21st century, BRICS countries need to strengthen internal reforms, actively establish free trade zones, reduce tariffs on import and export of products, resolutely oppose trade protectionism and actively promote the realization of trade liberalization. 


\section{Promote the Bridging of the "BRB" and "Belt and Road Initiatives"}

On the one hand, as the solidarity backing of the "Belt and Road Initiative", BRICS countries have their own advantageous industries. China has a comparative advantage in manufacturing industry. Russia has international competitiveness in primary products, especially oil and gas. India, on the other hand, Strong ability in computer and software applications, modern agriculture in Brazil has a comparative advantage, South Africa's mineral resources mining technology for all to see. On the other hand, the "Belt and Road Initiative" has provided new development opportunities for the BRICS countries. New challenges have been raised in the new century. All countries are actively seeking new ways of industrialization in the process of industrial upgrading and transformation. In order to achieve faster and better development All countries along the Belt and Road have put forward corresponding policies in this regard. Therefore, the BRICS countries need to strengthen the strategic docking with the countries along the Belt and Road initiative, actively seek appropriate points of interests and promote economic and trade cooperation among all countries.

\section{References}

[1] Jinping Yu,Comparative Advantage and Trade Complementarity between China and Major Countries and Regions in East Asia ,J. The Journal of World Economy.5 (2003) 33-40.(In Chinese)

[2] Daoxian $\mathrm{Yu}, \mathrm{Lu}$ Wang ,Study on the International Competitiveness of BRICS Service Trade-From the Perspective of Trade Value Added and Global Value Chain, J. The Journal of World Economy.8 (2016) 36-46.(In Chinese)

[3] Yanxin Cui,Tuo Wang, Analysis of Development Potential of BRICS Service Trade,J.Intertrade.8 (2017) 55-60.(In Chinese)

[4] Lijun Jia,An Empirical Analysis of the Complementarity in Trade between China and Major Countries in Latin America, J. Word Economy Study.11 (2005) 85-89.(In Chinese)

[5] Xiyan Yang,Di Wang, Analysis of the Complementarity between China and Russia in Trade,J.Word Economy Study.7 (2005) 71-77.(In Chinese)

[6] Jianguo Huo, Chaoran Peng, Prospects and Countermeasures of Economic and Trade Cooperation between BRIC Countries,J.Intertrade.9 (2017) 38-43.(In Chinese)

[7] Pingyao Lai, Jingyun Wu, Opportunities and Challenges Facing the Economic and Trade Cooperation between BRICS,J. Statistical Research.2 (2012) 22-27.(In Chinese)

[8] Yanmei Tian, The Impact of Sino-Korea Free Trade Area on the Goods Trade in Shandong Province - An Empirical Analysis Based on Gravity Model, J. Journal of Commercial Economics.22 (2017) 138-141.(In Chinese)

[9] Yeqiang Geng, Research on the Dynamic Growth of Bilateral Trade Between China and BRIC Countries,J.On Economic Problems.11 (2015) 65-71.(In Chinese)

[10] Armstong,Shiro, Measuring trade and trade potential: A survey, Working paper.(2007). 